\title{
Climate Change and the Niger Delta Region
}

\author{
A. A. Adewumi \\ Dept. of Zoology and Environmental Biology, \\ Ekiti State University, Ado Ekiti \\ 0. R. Agunbiade \\ Dept. of Zoology and Environmental Biology, \\ Ekiti State University, Ado Ekiti \\ 0. 0. Longe \\ Dept. of Crop Production and Health, \\ Ekiti State University, Ado Ekiti \\ 0. O. Fadiya \\ Dept. of Zoology and Environmental Biology, \\ Ekiti State University, Ado Ekiti \\ I. K. Adewumi \\ Dept. of Civil Engineering, \\ Niger Delta University, Amasoma
}

\begin{abstract}
The Niger Delta is located in the Atlantic coast of southern Nigeria where River Niger divides into numerous tributaries. It is the second largest delta in the world with a coastline spanning about $\mathbf{4 5 0}$ kilometres. It is the richest wetland in the world, highly diverse and supportive of numerous species of terrestrial and aquatic flora and fauna and human life. The Niger Delta is faced with myriads of environmental problems caused by climate change and the activities of multinational oil companies operating in the region. The occurrence of coastal erosion, rise in sea level, renewable resource degradation had been reported. Climate change has affected rainfall pattern with the consequent effect on vegetation and thus agriculture. Sea-level rise and repeated ocean surges will not only worsen the problems of coastal erosion that are already a menace in the Niger Delta, the associated inundation is increasing problems of floods, intrusion of sea-water into fresh water sources and ecosystems destruction thus destabilizing the mangrove, and affecting agriculture, fisheries and general livelihoods. Coastal erosion is the most important impact of sea level rise in the region and should be given high priority attention. With the distruption/destruction of the coastal ecosystem, loss of habitat and the climate getting warmer, the fish population is affected. Coastal erosion and flooding moulder the fertilizing eggs and fry of fishes thus affecting recruitment into the population. Several roads have been made impassable. Settlements in the coastal region, especially in Forcados, with some oil wells, have been uprooted by coastal erosion. It is predicted that Nigeria will lose about $\$ 9$ billion as a result of the sea level rise while at least $80 \%$ of the people of the Niger Delta will be displaced due to the low level of the region. A participatory, integrated approach to development is the solution. Government-private-sector partnership as well as partnership with other actors should be an integral part of the integrated approach.
\end{abstract}

Keywords: coastal, erosion, fry, fish, smouldering, 


\section{INTRODUCTION}

Nigeria is one of the countries expected to be most affected by the impacts of climate change, through sea level rise along our $800 \mathrm{~km}$ long coast line, intensified desertification, erosion and flooding disasters and general land degradation. One prediction is that 'Nigeria will lose close to $\$ 9$ billion as a result of the catastrophe while, at least, 80 per cent of the inhabitants of the Niger Delta will be displaced due to the low level of the oil-rich region. ..' (Guardian, Monday September 17,2001, p.80). As Nigeria's economy improves, its per capita greenhouse gas emissions may approach those of the developed nations of the world today. This, combined with continued gas flaring and a large population, will further worsen Nigeria's standing as a key emitter of greenhouse gases global

(http://www.climatenetwork.org/profile/member/nigerian-environmental-studyactionteam-nest ).

The Niger Delta is located in the Atlantic Coast of southern Nigeria where River Niger divides into numerous tributaries. It is the second largest delta in the world with a coastline spanning about 450 kilometres terminating at the Imo River entrance. The region spans over 20,000 square kilometres and it has been described as the largest wetland in Africa and among the three largest in the world. About 2,370 square kilometres of the Niger Delta area consist of rivers, creeks and estuaries and while stagnant swamp covers about 8600 square kilometres. The delta, with mangrove swamps spanning about 1900 square kilometres has the largest mangrove swamps in Africa. The region falls within the tropical rain forest zone. The ecosystem of the area is highly diverse and supportive of numerous species of terrestrial and aquatic flora and fauna and human life. It is the richest wetland in the world (Iyayi, 2004). The region is divided into four ecological zones namely coastal inland zone, mangrove swamp zone, freshwater zone and lowland rain forest zone.

Politically, the Niger Delta area cuts across nine states in southern Nigeria which include Abia, Akwa Ibom, Bayelsa, Cross River, Delta, Edo, Imo, Ondo and Rivers States. The region has emerged as one of the most ecologically sensitive region in Nigeria. Resources (oil and gas) from the region are the main source of revenue for the Nigerian state, accounting for about $97 \%$ of the country's total export. Like in other parts of the world, the climate change is already having its toll on the Niger Delta which is economic bedrock of the nation. This paper examines some of the glaring impacts and suggests possible mitigation measures. .

\section{Coastal Erosion and Flooding}

According to the International Federation of Red Cross (IFRC, 1999), sea level rise and flooding are already affecting millions of people worldwide. IFRC report revealed that an estimated 10 million people are at constant risk of coastal flood and floods in general are making 3 million people homeless every year, and that the number of people affected by sea level rise is on the increase annually. The occurrence of serious flooding and coastal erosion has been reported in the Niger Delta (Figs. 1 and 2) by Okon and Egbon (1999). The report of Udofa and Fajemirokun (1978) showed a rise in sea level along Nigerian coastal water. They did a mechanical analysis of tide data from 1960 - 1970 and reported mean sea level rise to be $0.462 \mathrm{~m}$ above zero level of the tide gauge. 


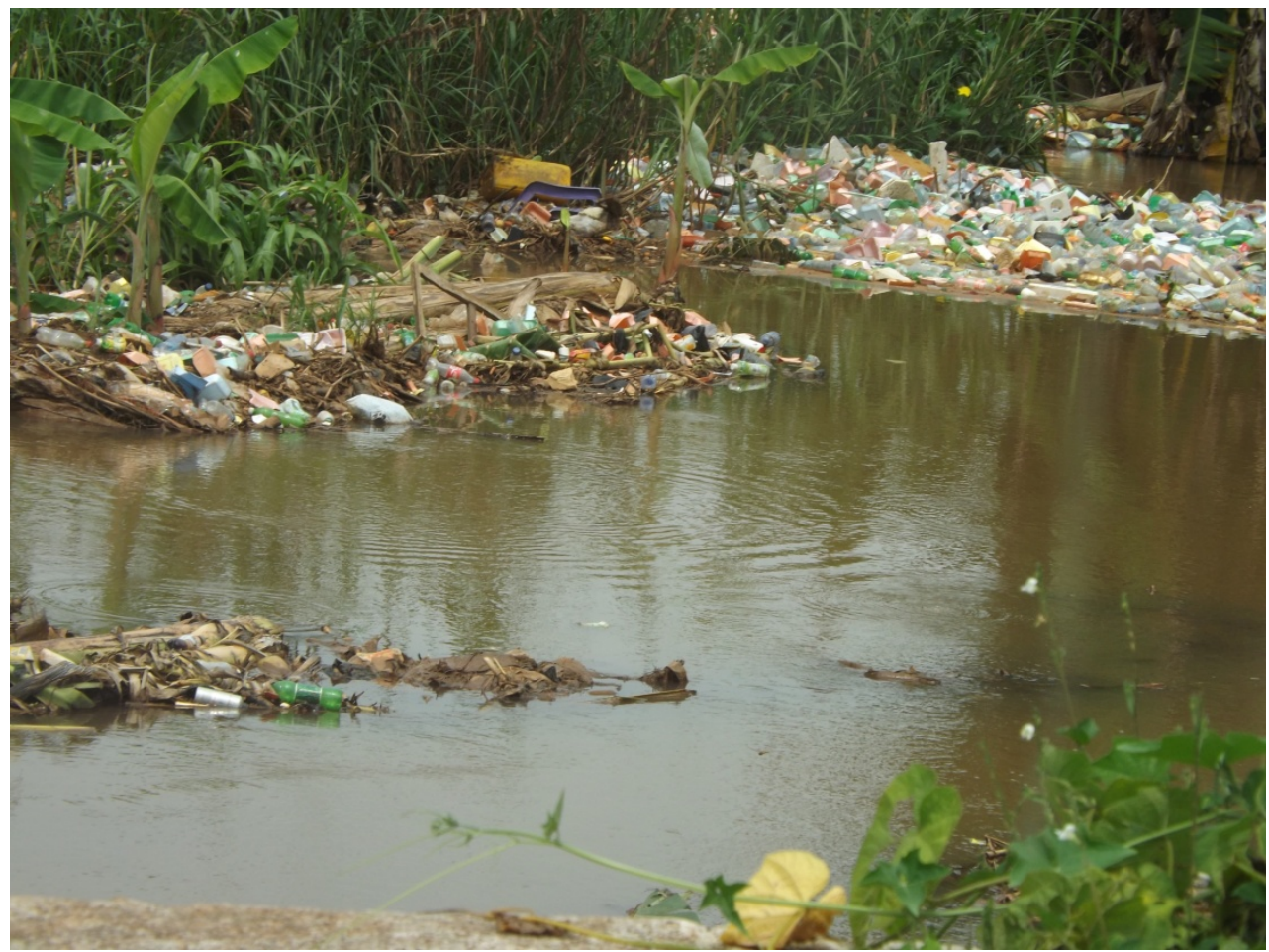

Fig. 1: Flooding in the Niger Delta region, causing solid wastes to be washed into a river body

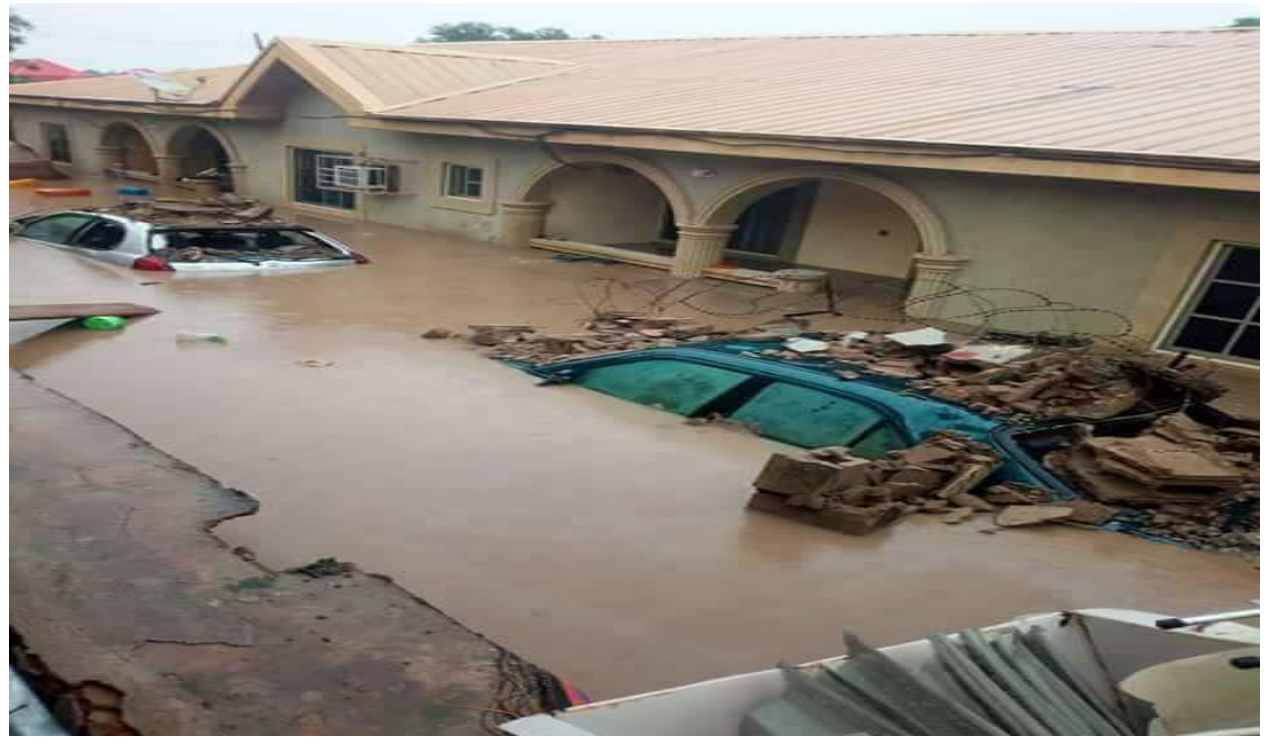

Fig. 2: Flooding causing drowning of cars and houses.

Agboola and Olurin (2003) reported that the World Bank ranked coastal erosion as needing moderate priority attention in the Niger Delta. Also, the Nigerian Environmental Study/Action Team (NEST), reported that sea-level rise and repeated ocean surges will not only worsen the problems of coastal erosion that are already a menace in the Niger Delta, the associated inundation is increasing problems of floods, intrusion of sea-water into fresh water sources and ecosystems destroying such stabilizing system as mangrove, and affecting agriculture, fisheries and general livelihoods (NEST, 2004). 
Table 1: Ranking of Environmental Issues in the Niger Delta by World Bank

\begin{tabular}{llll}
\hline Category & High Priority & Moderate Priority & Lower Priority \\
\hline $\begin{array}{l}\text { Land Resource } \\
\text { Degradation }\end{array}$ & $\begin{array}{l}\text { Agricultural Land } \\
\text { Degradation, Flooding } \\
\text { (Moderate high) }\end{array}$ & $\begin{array}{l}\text { Coastal Erosion, River } \\
\text { bank erosion }\end{array}$ & Sea level rise \\
\hline $\begin{array}{l}\text { Renewable resource } \\
\text { degradation }\end{array}$ & $\begin{array}{l}\text { Fisheries depletion, } \\
\text { Biodiversity loss }\end{array}$ & $\begin{array}{l}\text { Water hyacinth } \\
\text { expansion }\end{array}$ & $\begin{array}{l}\text { Fisheries habitat } \\
\text { degradation }\end{array}$ \\
\hline $\begin{array}{l}\text { Environmental } \\
\text { pollution., }\end{array}$ & $\begin{array}{l}\text { Sewage, Vehicular } \\
\text { emission, Municipal }\end{array}$ & $\begin{array}{l}\text { Oil pollution, } \\
\text { Industrial effluent, }\end{array}$ & Gas flaring \\
& $\begin{array}{l}\text { solid wastes, Toxic \& } \\
\text { hazardous substances }\end{array}$ & $\begin{array}{l}\text { Industrial air emission, } \\
\text { Industrial solid wastes }\end{array}$ & \\
\hline
\end{tabular}

The most important environmental problem facing the Niger Delta is coastal erosion. Although the World Bank has rated coastal erosion as needing moderate attention in the region, it is the most important impact of sea level rise in the region and should be given high priority attention. Flooding of low-lying areas in the region has been observed. Settlements in the coastal region have been uprooted by coastal erosion. In some places, especially in Forcados, some oil wells have been lost to the ocean due to erosion.

The Niger Delta could lose over 15000 square kilometers of land by the year 2100 with a one meter rise in sea level. Calculations have also shown that a $20 \mathrm{~cm}$ rise in sea level will inundate $3400 \mathrm{~km} 2$ of the Nigerian coast land (Table 2) (Onofeghara, 1990). It is estimated that with a sea level rise of $30 \mathrm{~cm}$, about 1 to 2 million people will be affected. In all this, it is predicted that Nigeria will lose about $\$ 9$ billion as a result of the sea level rise while at least $80 \%$ of the people of the Niger Delta will be displaced due to the low level of the region.

Table 2a: Total land loss $\left(\mathrm{Km}^{2}\right)$

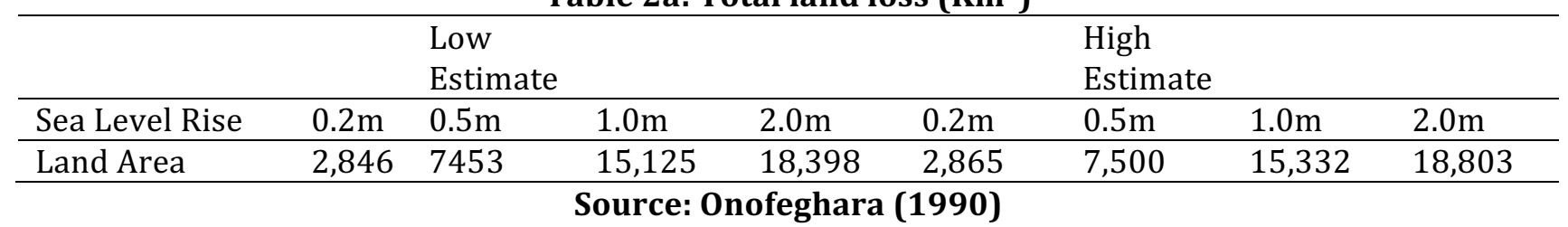

Table 2b: Estimated number of people (in millions) displaced by sea level rise at different scenarios of sea level rise

\begin{tabular}{lllll}
\hline Sea Level Rise & $0.2 \mathrm{~m}$ & $0.5 \mathrm{~m}$ & $1.0 \mathrm{~m}$ & $2.0 \mathrm{~m}$ \\
\hline People & 0.10 & 0.25 & 0.47 & 0.21 \\
\hline \multicolumn{5}{c}{ Source: Onofeghara (1990) }
\end{tabular}

The salinization of underground water will lead to shortage of fresh water. Inhabitants of the region depend on underground water as their main source of water for drinking and for other domestic use. Other impact of sea level rise on the region is the emergence of health-related hazards.

\section{Impacts on Agriculture and Fisheries}

Coastal erosion poses serious problem for the economic activities in the Niger Delta especially natural sectors such as farming and fisheries. Fisheries and aquaculture are vulnerable to climate change with profound impacts on the communities that depend on them. However, their vulnerability depends on the potential impact (sensitivity plus exposure) and the adaptive capacity of the systems and African fisheries, including Nigeria, are more vulnerable due to ecological (semi-arid and coastal locations) and social (large dependence on fish for protein, low adaptive capacity, weak economies and low human capacity development) factors (Worldfish Center, 2007). In Nigeria, the livelihood of about 26million people in fishing 
communities in coastal areas and their socio-cultural ties with lacustrine habitats. About 300 000 fish farmers, consumers depend on fish for protein supply and the present 4\% contribution of the fisheries sub-sector to agricultural sector's contribution of $40 \%$ to the GDP. About $50 \%$ of the fish consumed in Nigeria is from the Niger Delta. Coastal vegetation especially the mangroves have been lost to coastal erosion (Awosika, 1995). The Niger River/delta is an important ecosystem that needs to be protected, for it is home to 36 families and nearly 250 species of fish, of which 20 are endemic, meaning they are found nowhere else on earth (Chidumeje et al., 2015). It is common knowledge that scientists have estimated that $3 / 4$ of the tropical world's fish catch is dependent on mangrove forests for food or habitats.

Mangrove forests serve as nurseries and breeding grounds for both near-shore and off-shore marine species. Again, studies have shown that about $60 \%$ of the fishes in the Gulf of Guinea breed in the mangrove of the Niger Delta (Odiete, 1999). Fishes scatter eggs in leaves of aquatic thicket, bury eggs in sediments, guard eggs and juveniles in escavated nests (Bolarinwa, 2016). The shoreline along the Niger River is important in maintaining the temperature of the water because the slightest change in water temperature can be fatal to certain marine species of fish. Trees and shrubs provide shade and habitat for marine fish species, while reducing fluctuation in water temperature. With the distruption/destruction of the coastal ecosystem, loss of habitat and the climate getting warmer, the fish population is affected. Coastal erosion and flooding smoulder the fertilizing eggs and youngs of fishes thus affecting recruitment into the population. These habitats, and subsequently the fish assemblages associated with them, are potentially affected by a number of anthropogenic influences, some of which are depicted in Fig. 1. As most freshwater and marine fishes are cold blooded, the physiological and biochemical processes of the body function according to the dictates of the prevailing water temperature.

Other adverse effect of sea level rise in the Niger Delta is increased salinity of both surface and underground water due to the instruction of sea water. This will lead to the death of aquatic plants and animals that cannot tolerate high salinity. The brackish water is the home of several species of fishes and it is the breeding sites for several others. The ecology of the brackish waters will greatly be affected by this phenomenon and this may lead to loss of species. Some terrestrial plants that have low tolerance for high salinity will also be affected. Sea water rise will have serious impact on food security in the region; because of it impacts on coastal agriculture. 


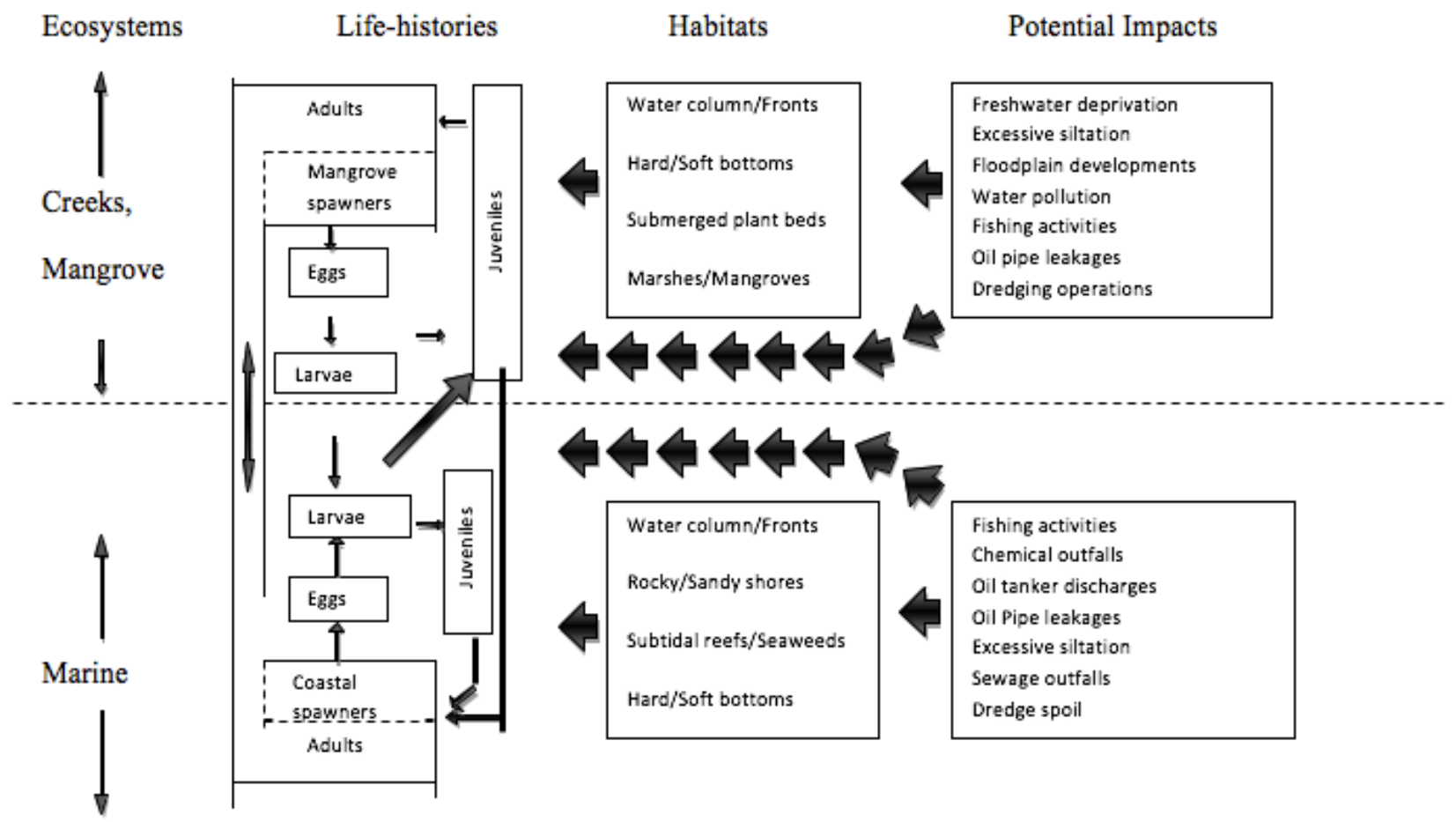

Fig. 1: Diagram (adapted from Hoss and Thayer, 1993) showing potential environmental modifications to fish habitats and life history stages, as can be applied to the Niger Delta area.

\section{Socio-economic Impacts}

While climate change will lead to increased aridity and desertification in northern Nigeria, it will lead to increase in flooding in the southern part especially in the coastal regions. Adverse impact resulting from the phenomenon will increase if sufficient effort is not made globally to tackle the problem.

Apart from coastal erosion, flood in general has impacted negatively the livelihood of many communities in the region. Flood and erosion remove top soil, destroy roads, affect fresh water resources and threaten lives and properties. Many people have been rendered homeless by floods and several roads have been made impassable or even washed off. The usefulness of several roads has become seasonal, only passable during the dry months of the year. In Egor and Ogida communities in Edo State, several houses have been abandoned by the owners due to floods and many more areas in the region are vulnerable to floods. Owners of the affected houses did not anticipate the problem they now find themselves when their houses were being built. For occupants of some of the affected houses who are unable to relocate for financial reason will have to cope with the situation. This makes them vulnerable to different kinds of water-related disease such as malaria, dysentery, cholera, and diarrhea. Trauma resulting from the problem can lead to non-pathogenic diseases such as hypertension and diabetes. In some other instances, some areas are cut off from other parts of the community as a result of flood.

Floods paralyze economic activities in many towns and cities in the region. Major roads, some linking states are flooded causing hardship to motorists. When these roads were constructed, the flooding problems were not there, and the companies that constructed the roads probably did not anticipate the problem. One common consequence of flooding is increase in transport fare. Commercial drivers, to make up for the distance they drive to avoid flooded roads, usually increase their fare putting the burden on their passengers causing the general increase in the cost of goods and services. 


\section{Change in Vegetation}

One important feature observed in the region is the almost complete absence of primary forests. This may be partly due to climate change and partly due to human activities. Uncontrolled logging, agricultural activities, acid rain, oil exploration and exploitation, urbanization and mining activities contribute to lose of vegetation. The vegetation of some part of the Niger Delta is dominated by grasses, sedges and shrubs with few scattered trees and they were mainly palm trees. In other parts, trees grow close to one another to form thick canopy over undergrowths.

The changes in vegetation will have great implication for biological productivity consequently affecting biomass production. It will lead to the impoverishment of biodiversity and various plant species presently growing in the region may die off. The regeneration rate of biomass may also decline significantly affecting the amount of fuel wood available for local people. Fall in the availability of biomass for local energy generation will bring more hardship to local people. Many will have to travel long distance in search for fuel-wood, women and children will be affected the most since they are traditionally charged with the responsibility of fetching fuel wood for the house.

\section{Change in Rainfall Pattern}

Meteorological data have shown that rainfall pattern in Nigeria has changed in the past decades. Oladipo (1995) reported that the decline in rainfall in Nigeria started at the beginning of the 1960s when a decade of relatively wet years ended. According to him, the persistence of below-mean rainfall in the last two decades in Nigeria is an indication of an abrupt change in climate. The Niger Delta lie predominantly in the tropics having two seasons - the wet and dry seasons. The wet season occur from May to September, while the dry season begins in October and ends in April.

Food security has been defined as the ability of people to grow and obtain food (Sarah La Trobe, 2002). The agricultural sector in Nigeria is highly sensitive to rainfall pattern especially in southern Nigeria where rain-fed agriculture is mainly practiced. It has been predicted that climate change will pose serious threat to food security. Climate change creates uncertainty in the rainfall pattern (timing and amount) and affects agricultural activities.

Agriculture in the Niger Delta is highly dependent on rain; and irrigation is seldom practiced. The changes in the rainfall pattern have greatly affected the agriculture in the region (Uyigue and Agho, 2007). Farmers in the region begin cultivation at the end of the dry season, when the rain begins to fall. They plant their crops after the first or second rain in the month of March, and sometime in April. After the first rain, the rain falls periodically till the months of June/July (the peak of the rainy season), when rain fall more or less continually. The periodic rainfall pattern before the peak in June enables farmers to cultivate various crops.

Because of the change in rainfall pattern, farmers who plant after the first or second rain in run into huge loss when the rains are delayed beyond the usual due to climatic changes. The crops are scotched causing huge economic loss. Before this time farmers can predict the rain and they know precisely when to plant their crops. The crops after they are planted are watered periodically by rain before the peak of the rainfall in June. The amount of rainfall within the period before the peak is necessary for the optimum performance of many crops most especially the maize which is widely consumed in every part of Nigeria. In an investigation (Onwuemele, 2015), it was reported that more than $80 \%$ of households have diversified their livelihoods into the non-farm sector with serious implications for food security. There is 
therefore, need for support for local farmers to enhance their capacity to adapt to climate change to improve their agricultural practices.

\section{Integrated Approach to Developing the Niger Delta}

The Niger Delta is faced with myriads of environmental problems caused by climate change and the activities of multinational oil companies operating in the region. We therefore propose an integrated approach in solving the problem in the Niger Delta. By an integrated approach, we mean a combination of several development strategies packaged into one piece in a way that it will be more effective. The integrated approach must be participatory. The local people are the primary targets of development and development can only be precisely defined by them. It is only the definition of the local people to whom development strategies is directed at, that is acceptable. Thus every development strategic must seek to view development from the perspective of the local people. The United Nations Declaration on the Rights to Development of 1986 recognized that the human person is the central subject of the development process and that development policy should therefore make the human being the main participant and beneficiary of development.

The integrated approach must x-ray the needs of the local people and design an allencompassing strategy to address these needs. The needs of the local people vary from community to community and among the different groups in the society - the men, women and youths. An integrated approach will target the different groups. It is of utmost importance to conduct detailed studies to ascertain the priority needs of communities before embarking on any project. The needs of the various communities should be addressed in order of priority, starting from the most important to the least. For example, if the priority need of a particular community is the provision of portable drinking water, the people may feel dissatisfied if they are provided with electricity.

Integrated approach must also seek to understand the existing coping strategies of the local people to changes in their environment and build on them through policy formulation with adequate participation of the local people. An effective coping strategy will reduce vulnerability to climate change and other changes in the environment. An in-depth understanding of how individuals, communities and natural system can prepare for and respond to changes in climate and non-climate shocks is important to reducing vulnerability to adverse changes in the environment.

In this integrated approach, all actors should be involved - the government, international organizations, civil society based organizations, non-governmental organizations, the private sector, academia, agencies of the United Nations, financing organizations like the World Bank and the communities. The government as a primary developmental partner should work closely with grassroots organizations that are privileged to have good knowledge of the communities. Government-private-sector partnership as well as partnership with other actors should be an integral part of the integrated approach.

While it is a palpable truism that industrialization enhances socio-economic development, it is important to note that industrialization without the right technologies is unsustainable and may become inimical to the local people. This is the case in the Niger Delta. Industrial development should be accomplished with technologies that are environmentally friendly. The multinational oil companies operating in the region should develop technologies that will minimize the impact of their activities on the environment. For instance, old-fashioned flaring of gas can be replaced by converting the gas into other useful products. Chemical experts are on the opinion that instead of flaring gas, it can be converted to alcohol and put into diverse 
uses. The government and the multinational companies should be involved in environmental restoration activities. Such activities may include aforestation, support for sustainable agriculture and fishery, establishment of environmental management institutions and research institution, and policy formulation for the preservation of wildlife and other endangered species.

There cannot be enjoyment of any resources if the people do not have control over their resources. It is a case of forcefully taking from the people what belongs to them and given it to somebody else. This is unethical and legislations supporting such acts are criminal. If resources are discovered in any community that are of commercial value for the state, the government should carry out adequate consultation with the community and enter into agreement with them before the exploitation of the resources. The consultations and agreements should be well documented. The provision in the Nigerian constitution vesting the control of all resource in Nigeria solely in the states should be repealed. The constitution should therefore allow the local people gain control of the resources from their land.

In the Nigerian constitution, at the bridge of environmental rights, there is no provision for individuals, agencies and communities to sue for enforcement of environmental rights. The power to sue for environmental rights is vested only in the state. The question is what happens when the state or it collaborators are the one directly involve in the bridge of environmental rights? Therefore, provision should be given in the constitution to allow individuals, communities and agencies to sue for enforcement of environmental rights. When there is a breach in environmental rights, individuals, groups and communities are the ones affected. For sustainable development to be achieved in the Niger Delta, the region must gain control of their land and mineral resources taken away from them through military decrees that have been enacted into laws in the Nigerian constitution.

\section{CONCLUSION}

The Niger Delta is faced with myriads of environmental problems caused by climate change and the activities of multinational oil companies operating in the region. A participatory, integrated approach to development is the solution. Government-private-sector partnership as well as partnership with other actors should be an integral part of the integrated approach.

\section{References}

Agboola, T. and Olurin, T. A. (2003) Land use and Land cover change in the Niger Delta.

Excerpts from a Research Report presented to the Centre for Democracy and Development, July, 2003.

Awosika, L.F. (1995). Impacts of global climate change and sea level rise on coastal resources

and energy development in Nigeria. In: Umolu J.C (ed.). Global Climate Change: Impact on energy development. DAM TECH Nigeria Limited, Nigeria

Bolarinwa, J.B. (2016). Length- weight relationships and condition factors of Oreochromis niloticus and Chrysichthys nigrodigitatus in Mahin lagoon, Nigeria. Res. J. Agri. Environ. Manage. 5(3):075-080.

Chidumeje, N.P.; Okonkwo, L. K. and Subhashni, T. (2015). The Niger Delta wetland ecosystem: What threatens it and why should we protect it? Afr. J. of Env. Sci. and Tech. 9(5):451-463.

http://www.climatenetwork.org/profile/member/nigerian-environmental-studyaction-team-nest

Why should Nigeria be concerned about climate change?

IFRC (1999). http://www.ifrc.org/en/publications-and-reports/world-disasters-report/wdr1993-1999/

NEST (2004). Executive Summary of Five Multi-Sector Surveys on Nigerian's Vulnerability and Adaptation to Climate Change, Ibadan, Nigerian Environmental Study/Action Team (NEST) and Global Change Strategies International (GCSI) Canada 
Odiete, W. O., (1999). Environmental Physiology of Animals and Pollution, 1st ed. Diversified Resources Limited, Lagos.1-end.

Okoh, R. N. and Egbon, P. C. (1999). Fiscal Federalism and Revenue Allocation. The Poverty of the Niger-Delta. In: Aigbokhan B.E(eds). Fiscal Federalism and Nigeria's Economic Development. Selected Papers of the 1999 Annual Conference of the Nigerian Economic Society (NES), Ibadan. p57-61.

Oladipo, E.O. (1995). An indication of abrupt change of rainfall and it potential impact on energy development in Nigeria. In: Umolu, J. C. (ed). Global Climate Change: Impact on Energy Development. DAMTECH Nigeria Limited, Nigeria.

Onofeghara, F.A. (1990). Nigerian Wetlands: An Overview. In: Akpata, T.V.I and Okali, D. U.U. (eds). Nigerian Wetlands pp 14-26. Man and the Biosphere (MAB) National Committee, Nigeria, UNESCO National Commission, Federal Ministry of Education.

Onwuemele, A. (2015). Livelihood responses to climate change in the Niger-Delta: Implications for food security in Nigeria. Int. J. of Dev. and Management Rev. 10(1): 1-11.

Sarah La Trobe (2002). Climate Change and Poverty. A discussion Paper. A publication of Tearfund, UK.

The WorldFish Center (2007). The threat to fisheries and aquaculture from climate change. The WorldFish Center. Penang, Malaysia. 8p.

Udofa, I. M. and Fajemirokun, F. A. (1978). On a height datum for Nigeria. In Proceedings of the International Symposium on Geodetic Measurements and Computations. Ahmadu Bello University, Zaria, Nigeria. p70.

Uyigue, E. and Agho, M. (2007). Coping with Climate Change and Environmental Degradation in the Niger Delta of Southern Nigeria, Community Research and Development Centre (CREDC) Nigeria. http://www.globalgreenhouse-warming.com/climate-change-in-Niger-Delta.html 